\title{
Factors Influencing Risk of Shallot by Using Arch Garch and Var
}

\author{
Ratna Mega* sari And Yeni Budiawati \\ Department of Agribusiness \\ University of Sultan Ageng Tirtayasa \\ Serang, Indonesia \\ *ratna.megasari@untirta.ac.id
}

\begin{abstract}
Some of the horticultural commodities that have been assigned to be excellent commodities in the period 20152019 are various chili, shallot, and orange. Shallot are strategic commodities in Indonesia as well as commodities with high price fluctuations compared to other horticultural commodities. The aims of this study are to analyze factors influencing price risk of shallot in Indonesia and to a analyze strategy regarding to price risk of shallot in Indonesia. Processing and data analysis is conducted by using regression, ARCH GARCH and VAR model. Based on regression model, Price of shallot is influenced by supply. The results of the analysis concluded that the Best ARCH GARCH model for shallot price risk is ARCH (1) GARCH (1). It means that price risk of shallot is influence by volatility of previous day and variance of previous day. Efforts to overcome price volatility of shallot can be done through an integrated effort between farmers, government traders and other parties. Cooperation undertaken between the various parties should be accompanied by consistency and strong commitment such as continuous coaching and good supervision. This is done so that in an effort to achieve the expected results can be more efficient.
\end{abstract}

Keywords : Price, Risk, Shallot

\section{INTRODUCTION}

\section{Background}

Plantations Horticulture is an important sub-sector of agriculture because it has a function in food supply, economic, health, and socio-cultural. The function of providing food in the form of sources of vitamins, minerals, fiber and other compounds for the fulfillment of nutrition. Economic functions in the form of sources of income for various groups include farmers, traders and industry. Health functions are obtained through the benefits of biopharmaceuticals to prevent and treat various diseases. While the socio-cultural function is shown by the role of horticultural commodities as one of the elements of environmental beauty and comfort.

The horticultural subsector is one of the sources of new economic growth as a driver of the rural and urban economy. At present the role of the horticultural subsector is quite significant in national economic development. Some indicators that show this are: Contribution of the horticulture sub-sector in the national macro economy such as GDP, Labor, Trade Balance and others.

So far the contribution of horticultural agriculture (fruits and vegetables) to GDP tends to increase. In 2009 the
GDP of fruit horticulture agriculture was $\mathrm{Rp} 132.01$ trillion and increased to Rp 153.69 trillion in 2014 with an increase of 5.63 percent while the GDP of vegetable horticulture agriculture increased from 2009 to 56.82 trillion to 73.78 trillion with an increase of 9.86 percent (Ministry of Agriculture, 2015)

The rate of growth of horticultural exports for the last five years also shows a positive value in the span of one year. that is 6.57 percent per year which is a contribution from the growth rate of export value from floriculture 29.64 percent, 7.18 percent fruit and vegetables 7.16 percent and medicinal plants 6.01 percent (Ministry of Agriculture, 2015).

The Directorate General of Horticulture has several assisted commodities which include 323 types of commodities consisting of: 60 types of fruits, 80 types of vegetable commodities, 66 types of commodities of medicinal plants and 117 types of floriculture commodities. Determination of superior commodities is based on the following criteria: 1) impact on the macro economy, 2) production, 3) area, 4) export potential, 5) import substitution, 6) number of business actors, 7) economic value, 8) potential value added, 9) technology availability, 10) industrial raw material requirements, 11) domestic demand, 12) relative market share in commodity groups.

\section{Problem Formulation}

This price fluctuation is a risk faced by farmers, traders and consumers. At times, prices are very high, but not for long, prices can drop dramatically. Price fluctuations in several horticultural commodities can be seen in the following figure. 


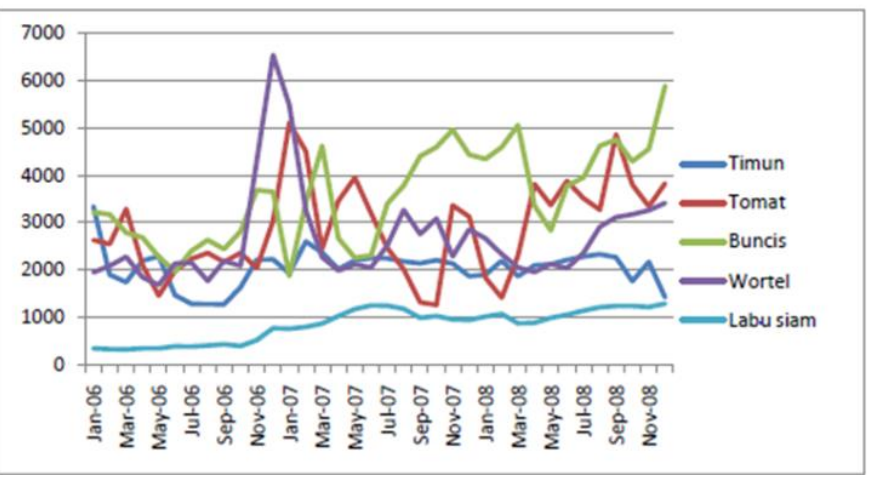

Figure 1. Price fluctuation of horticulture commodity Source : (Wihono, 2009)

The fluctuating price of horticultural commodities can produce positive and negative effects. When the price of vegetables is high, sellers and farmers of horticultural commodities will get substantial profits, but consumers get losses due to rising prices of goods. While the negative influence caused to traders due to fluctuations in horticultural commodity prices is when prices of horticultural commodities are low. In these conditions vegetable sellers will get a small profit. But this is otherwise beneficial to consumers.

Price fluctuations can be caused by the large number of offers and the large number of requests. The higher the number of bids, the lower the price, on the contrary if the number of offers decreases, the price will increase (cateris paribus). The high and low number of offers can be caused by harvesting. The high rate of crop failure can be caused by pest attacks and weather factors. Judging from demand, high prices occur because the demand for a commodity increases. While the decline in demand will cause a decrease in prices (cateris paribus).

This fluctuating price makes this commodity difficult to predict. As an example of this case, this research will take place at the Kramat Jati Central Market (PIKJ). Every day the Kramat Jati Central Market receives hundreds of tons of vegetable supplies from various vegetable producing regions in Indonesia. In addition, changes in vegetable prices at the Kramat Jati Central Market are also recorded every day. So that with the recording of prices every day price fluctuations can be clearly observed.

Price fluctuations that occur also cause the Food Security Agency to experience difficulties in monitoring the price changes. The Food Security Agency found it difficult to set a price policy for these vegetables. Therefore we need an analysis of the level of risk of horticultural commodity prices so that price fluctuations can be immediately overcome. Measurement of risk level needs to be done to map the uncertainty. The level of risk that exists at the price in the Kramat Jati Central Market can provide an idea of the level of uncertainty that will be borne by farmers, sellers or buyers in the event of changes in horticultural commodity prices on the market.

Based on the formulation of the problem, the research objectives are:

1. Analyze the risks of several major horticultural commodities in Indonesia and the factors that influence them

2. Analyze alternative strategies related to the risk of prices of major horticultural commodities in Indonesia

\section{LITERATURE REVIEW}

\section{Risk Concept}

According to Harwood (1999) the risk shows the possibility of events that cause harm to business people who experience it. According to Kountur (2004), risk is related to uncertainty, this uncertainty occurs due to lack of information about what will happen. According to Robison and Barry (1987) the risk indicates an opportunity for an event that can be known by the decision maker based on experience. Risks also indicate the probability of events that generate income above or below the average of expected income.

From some of the definitions of risk, it can be concluded that risk is associated with the possibility of something bad happening or an undesirable or unexpected loss that occurs unexpectedly. Djohanputro (2004) classifies the risks of:

a. Pure and speculative risks

Pure risk is a risk that can result in a loss to the company, but there is no possibility of profit. While speculative risk is a risk that can be beneficial or detrimental.

b. Systematic or specific risks

Systematic risk is also referred to as a risk that cannot be diversified, ie risks that cannot be eliminated or reduced by combining various risks. Specific risks are risks that can be diversified through the pooling process

Every businessperson in the face of risk has different attitudes and behaviors. There are three characteristics of business people in responding to the risk, namely Risk Taker, Risk Averter and Risk Neutral which their behavior in dealing with risk can be seen in Figure 2 


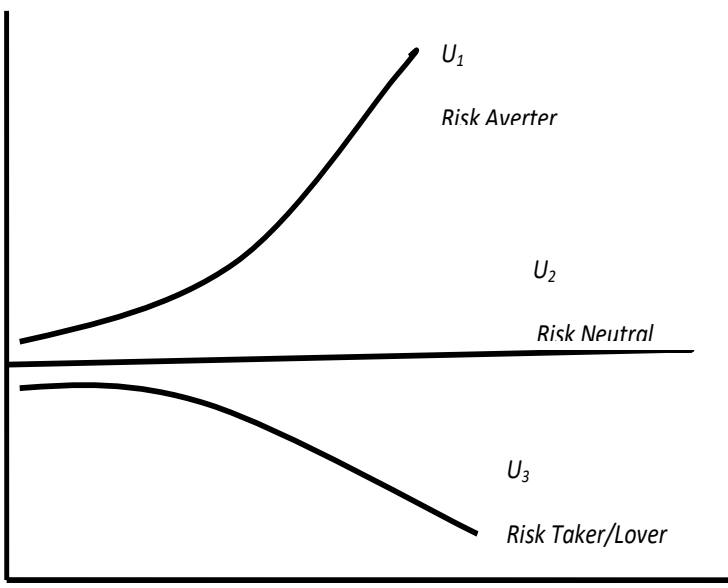

Figure 2 shows the relationship between variance return, which is a measure of the level of risk, with the expected return, which is the level of satisfaction of the decision maker. The attitude of decision makers in dealing with risk can be classified into the following three categories:

1. Risk Averter decision makers show that if U1 is assumed to be a decision making curve, then there is an increase in variance return which is a measure of the level of risk will be balanced by increasing the expected return.

2. Risk-neutral decision makers indicate that if U2 is assumed to be a decision-making curve of isoutilite, an increase in variance returns which is a measure of the level of risk will not be offset by increasing the expected return.

3. Risk-taker / Lover decision makers indicate that if U3 is assumed to be a decision-making curve for isoutilism, an increase in variance returns is a measure of the level of risk that will be balanced by the decision maker with the willingness to accept the lower expected return.

Other forms that can describe individual behavior in dealing with risk can be seen in Figure 3 which shows individual satisfaction with regard to income possibilities.

\section{Agricultural Risk}

The agricultural sector is inseparable from risk conditions caused by several factors or sources. Agricultural risk sources according to Anderson et al. (1977) divided into three, namely:

1. Uncertainty of production

The uncertainty of production results is caused by the agricultural sector which is very dependent on nature such as weather and climate, pests and diseases, air temperature, changing seasons and so on. The production risk has a significant effect on production and revenue activities.

2. Price uncertainty

Price fluctuations in agricultural products are caused by natural factors and demand and supply. The higher the level of demand, the higher the price of agricultural products, and vice versa. Thus, the more fluctuating the price, the greater the price risk.

3. Uncertainty of profits

Production risk and price risk can create a risk of profit. The higher the profit fluctuation, the greater the risk faced. Likewise, the lower the profit fluctuation, the lower the risk faced.

Farmers need to implement strategies that can reduce the chances of the emergence of risks that cause losses. According to Debertin (1986) there are several strategies that can reduce losses when nature and markets are in a condition that does not benefit farmers. Likewise, on the contrary, by implementing this strategy the profits that farmers will have will be reduced when natural conditions and markets are profitable. These strategies are

1. Agricultural Insurance

Agricultural insurance can be used as an alternative strategy that can reduce risk by purchasing insurance policies. If the farmer buys a fire insurance policy, it does not mean that the farmer expects the occurrence of fire. This is done because insurance costs are smaller than the possible risk costs that will be borne if a fire really occurs. Good insurance is insurance provided for events that have a small chance of occurring. Insurance is used for events that result in large losses but have a low probability. Agricultural insurance causes farmers' income to decrease due to paying insurance premiums. Insurance premiums reduce potential profits in one year where no adverse events occur in that year.

\section{Contract}

Future market is a system where farmers make sales contracts on certain commodities and prices. Therefore, the contract system is one of the ways taken in dealing with price risks. Future markets are a mechanism to reduce or eliminate risk and price uncertainty by determining prices that must be paid after harvest or when the commodity is ready to be marketed. Although prices and revenues will be reduced, farmers will limit potential profits if prices are determined at the start of the production season.

Future markets are not the only type of contract to eliminate price uncertainty. Some contracts with pricing at the start of the production season and receipts at the end of production will also eliminate price uncertainty. Contracts are usually used on commodities such as broilers and horticulture. Price contracts can work well in a marginal analysis model that presents price certainty.

3. Flexible equipment and facilities

If farmers can regulate product changes and input prices, farmers can also adjust buildings and equipment that can be used more than one production season and more than one type of agricultural product. Special facilities will allow farmers to have long-term planning. Farmers who try to overcome price uncertainty by purchasing buildings and machines that are adaptable to various uses will certainly have greater elasticity. 


\section{Diversification}

Diversification is a long-term strategy that farmers can implement to overcome price and output uncertainty. Diversification strategies essentially make profits from a type of farm or agricultural business to cover losses from other types of businesses. Diversification also makes the use of labor and inputs more effective throughout the year. Thus, fixed income is good even in favorable and adverse conditions. Therefore, to achieve more effective results, diversification should be carried out by commodities that have the opposite character.

\section{Government Programs}

The government can also play a role in overcoming price and production uncertainty faced by farmers. The role of the government can be in the form of support in the form of programs that can increase the income and welfare of participating farmers. Participation in the program normally will reduce income variability.

\section{RESEARCH METHODS}

\section{Location and Time of Research}

Research on the risk of commodity prices of large red chili and curly red chili and large red chili is carried out through data collection at Kramat Jati Central Market located at jalan raya Bogor KM 17 East Jakarta. The location of this study was chosen because the Kramat Jati Central Market is the largest horticultural commodity market in Indonesia which became the benchmark for commodity prices in regions in Indonesia. In addition, commodity prices at the Kramat Jati Central Market are one of the sources of information used by the Indonesian Ministry of Agriculture in determining policies. The study was conducted for five months, namely from February 2018 - June 2018.

\section{Data and Data Sources}

This research was conducted using primary and secondary data. Primary data was obtained through interviews with two traders, two employees of the Kramat Jati Central Market office and six farmers. Secondary data is obtained based on price and supply data that already exist in Kramat Jati Central Market, Ministry of Agriculture and other related literature.

\section{Method of collecting data}

The data source used in this study is the daily price data of the main horticultural commodities in 2011-208 which amounted to 1147 data. The data is obtained based on the existing price record at the Kramat Jati Central Market office. In addition, data collection is also carried out by interview, observation and discussion methods. Interviews were conducted with several Kramat Jati Central Market employees and traders and farmers cultivating market conditions and price fluctuations in the commodities under study.
Observation method is carried out through direct recording of market conditions, while discussions are held with employees of the Kramat Jati Central Market office regarding market conditions related to price fluctuations.

\section{Data Processing and Analysis}

The measurement of the price risk of the main vegetable commodity in this study uses the ARCH GARCH method which is used to predict volatility in the next period. The volatility of the forecasting results is then used to measure the risk of the price of the main vegetable commodity using the VaR (Value at Risk) calculation.

\section{Analysis of ARCH-GARCH}

\section{Identification Phase}

ARCH-GARCH modeling is preceded by the identification of whether or not the data contains heteroscedasticity. This can be done, among others, by observing some summary statistics from the data. Testing the existence of heteroscedasticity can be done by looking at the value of data (kurtosis). If the data has more than three kurtosis values then the data has heteroscedasticity (Davidson and MacKinnon, 2004 in Firdaus, 2006). Then, continued with testing the identification of the ARCH effect through the quadratic return autocorrelation function. A data has an $\mathrm{ARCH}$ effect if the autocorrelation value on the data is a significant return square. Another way that can be done in testing $\mathrm{ARCH}$ error is through the ARCH-LM test. ARCH-LM test is based on zero hypothesis that there is no ARCH error.

\section{Model Estimates}

Model estimation is preceded by the determination of ARCH GARCH parameter estimates. The determination of the ARCH-GARCH parameter is done using the iterative maximum probability method. Through the use of Eviews 5.0 software, estimation of parameter values can be done. the best model found is a model that has a large measure of goodness and a real coefficient. The approach that can be used to measure the goodness of the model is the AIC (Akaike Information Criterion) and SC (Schwarz Criterion)

$$
\begin{aligned}
& \text { a. } \mathrm{AIC}=\mathrm{Ln}(\mathrm{MSE})+2 * \mathrm{~K} / \mathrm{N} \\
& \text { b. } \mathrm{SC}=\mathrm{Ln}(\mathrm{MSE})+\left[\mathrm{K}^{*} \log (\mathrm{N})\right] / \mathrm{N} \\
& \text { Description: } \\
& \mathrm{MSE}=\text { Mean Squared Error } \\
& \mathrm{K} \quad=\text { quantity of estimated parameter } \\
& \mathrm{n} \quad=\text { observation quantity }
\end{aligned}
$$

AIC and SC are information standards that provide a measure of information that can find a balance between measures of model goodness and model specifications that are too economical. A good model is the model that has the smallest $\mathrm{AIC}$ and SC values by also looking at the significance of the model. 


\section{ARCH-GARCH Model Inspection Stage}

To ensure that the model obtained is adequate, a model check is carried out. If it turns out that the model found is inadequate, identification will be carried out again. Examination of the model can be carried out through standardized residual analysis through residual residuals, residual freedom as seen from the autocorrelation and residual quadratic functions, as well as testing the residual $\mathrm{ARCH}$ GARCH effects.

The ARCH-GARCH model shows good performance if it can eliminate autocorrelation from data, that is, if the standard residual is a white runny process. The next step is to examine the standard residual autocorrelation coefficient with the Ljung-Box statistical test.

\section{Forecasting Price Risk Levels}

The best model that has been found is used to forecast variance for the coming period. Forecasting results are used for VAR calculations. Variation forecasting for the next period is predicted using the following formula

$\mathrm{ht}=\xi+\cdot \varepsilon 2 \mathrm{t}+\cdot 1 \varepsilon 2 \mathrm{t}-1+\cdot 2 \varepsilon \mathrm{t}-2+\ldots \ldots+\cdot \mathrm{m} \varepsilon 2 \mathrm{t}-\mathrm{m}$

\section{VaR Calculation (Value at Risk)}

Value At Risk is a measure of the amount of risk that can currently be considered as a standard method in measuring market risk (market risk). Value At Risk is the biggest loss that may occur in a certain period / period that is predicted with a certain level of trust. follows

The formulas used in the calculation of VAR are as

$\mathrm{VAR}=(\sigma \mathrm{t}+1 \times \sqrt{ } \mathrm{b}) \times \mathrm{Z} \cdot \mathrm{x} \mathrm{W}$

Description:

VAR = Value at risk

$\mathrm{b} \quad=$ Investation Period

$\mathrm{Z} \cdot \quad=$ critic point in table $\mathrm{Z}$ with alfa $5 \%$

$\mathrm{W} \quad=$ investation cost

$\sigma \mathrm{t}+1=$ Future Volatility $\sigma \mathrm{t}=\sqrt{ } \mathrm{ht}$

Risk calculation in the main horticultural commodities is carried out by using the approach to farm income obtained by farmers in one production period and calculated based on the commodity sales period.

\section{RESULTS AND DISCUSSION}

Regression Model of Shallot

$\operatorname{lnPt}=1.671465+0.923723 \ln \mathrm{Pt}-1-0.145405 \ln \mathrm{S}+$ et

Where:

$\mathrm{Pt}=$ Shallot Price in $\mathrm{t}$ period

Pt-1 = Shallot price in previous period

$\mathrm{S} \quad=$ Shallot Supply
Based on the significance test with a real level of five percent, it can be seen that the previous price had a significant effect on prices at a certain time. Similarly, the significance test of the model shows that the amount of supply has a significant effect on prices at a given time.

Testing of the presence or absence of heteroscedasticity in the residuals in the chili price equation model was carried out using the ARCH LM test and the White Test. The ARCH LM test is based on the null hypothesis that there is no $\mathrm{ARCH}$ error. ARCH LM test results for the chili equation model can be seen in appendices 6 and 22. Table 12 shows a summary of ARCH LM test results for the equation model.

Table 1. ARCH LM Test of Shallot Model

\begin{tabular}{lllll}
\hline Jenis Uji & $\begin{array}{l}\text { Obs*R- } \\
\text { Squared }\end{array}$ & Probability & $\begin{array}{l}F- \\
\text { Statistic }\end{array}$ & $\begin{array}{l}\text { Probabili } \\
\text { ty }\end{array}$ \\
\hline Uji ARCH & 66.51183 & 0.0008 & 88.80306 & 0.0000 \\
LM & & & & \\
\hline Uji White & 20.49566 & 0.0010 & 4.347225 & 0.0000 \\
\hline
\end{tabular}

Based on the ARCH LM test in both models it can be seen that Obs * R-Squared has a small probability compared to $\alpha$ which is usually used, which is five percent. Thus, it can be concluded that the residuals above contain heteroscedasticity.

To overcome the existence of heteroscedasticity, price and supply data can be modeled using the ARCH-GARCH. Determination of the right ARCH-GARCH model is done by simulating multiple models. Estimation of model parameters using the maximum likelihood or quasi-maximum likelihood method. Model simulation combines the value of $r=0,1,2,3$ with the value of $m=1,2,3$. The choice of the best variance model is done by looking at one of the alternative models that have the lowest AIC and SC values and there is no $\mathrm{ARCH}$ effect. The results of the trial to get the best GARCH model can be seen in appendix 7 to attachment 20 shown in appendix 23 to appendix 36. Table 1 shows a summary of the results of the ARCH GARCH shallot model that no longer has ARCH or heteroscedasticity effect.

Table 2. The ARCH GARCH shallot model that no longer has $\mathrm{ARCH}$ or heteroscedasticity effect.

\begin{tabular}{lcc}
\hline Model & \multicolumn{2}{c}{ Error } \\
\hline & AIC & SC \\
\hline ARCH (1) GARCH (0) & -1.597079 & -1.528604 \\
ARCH (1) GARCH (1) & -1.589437 & -1.507267 \\
ARCH (1) GARCH (2) & -1.581661 & -1.485796 \\
ARCH (1) GARCH (3) & -1.562180 & -1.452621 \\
ARCH (2) GARCH (0) & -1.589432 & -1.507263 \\
ARCH (2) GARCH (1) & -1.494149 & -1.398284 \\
ARCH (2) GARCH (2) & -1.605235 & -1.495675
\end{tabular}




\begin{tabular}{lll} 
ARCH (2) GARCH (3) & -1.463095 & -1.339841 \\
ARCH (3) GARCH (0) & -1.509215 & -1.413351 \\
ARCH (3) GARCH (1) & -1.462791 & -1.353231 \\
ARCH (3) GARCH (2) & -1.442163 & -1.318908 \\
ARCH (3) GARCH (3) & -1.421389 & -1.284440 \\
\hline
\end{tabular}

The best ARCH GARCH model is selected through the smallest error criteria (AIC and SC) and there is no ARCH effect on the model which indicates that the model no longer contains heteroscedasticity. In addition the model is also chosen based on the absence of variables that are negative on variants and volatility. Based on these criteria the best ARCHGARCH model for chili is ARCH (1) GARCH (0). This means that the pattern of price movements of curly red chili is influenced by volatility one day before.

Based on the ARCH-GARCH model the best is shown by the equation

$h t=0.005495+0.881420 \varepsilon 2 t-1$

Based on the best ARCH-GARCH model, it can be calculated the amount of risk faced by farmers with fluctuations in the price of shallots through VAR calculations. The level of acceptance taken for the calculation of VAR comes from the total revenue received by farmers in one production period. Based on the calculation of VAR with a 95 percent confidence interval with the average average one-time production period with an area of one hectare is $\mathrm{Rp}$. $122,009,623.85$, the risks borne in the one-day, seven-day and thirty-day sales period can be seen in Table 3 .

Table 3. Shallot Risk based on farmer's income

\begin{tabular}{cccccc}
\hline \multicolumn{7}{c}{ Risk Degree } \\
\hline \multicolumn{2}{c}{ 1 Day } & \multicolumn{2}{c}{ 7 Days } & \multicolumn{2}{c}{ 30 Days } \\
\hline$*$ & $\%$ & $*$ & $\%$ & $*$ & $\%$ \\
\hline \multirow{2}{*}{0.37} & 3,05 & 0,98 & 8,07 & 2,03 & 16,70
\end{tabular}

Description: *in million rupiahs

The level of risk possessed by shallots is Rp. $3,719,434.77$ of the total revenues received in the amount of Rp. $122,009,623.85$ So that if there is an increase in revenue on shallots, the risk of the price of shallots also increases.

Based on Table it can be seen that the price risk of shallots is 3.055 percent of the total revenue received by farmers with a one-day sales period. This means an increase in revenue of one rupiah will increase the risk of shalloti by 3.05 percent.

The longer the sales period after harvest, the greater the risk borne by farmers. This can be seen from the increasing price risk in the 7 and 30 days sales period. The longer selling period will cause the shallot price so that the selling price of the shallot falls.

\section{CONCLUSION}

the Best ARCH GARCH model for shallot price risk is ARCH (1) GARCH (1). It means that price risk of shallot is influence by volatility of previous day and variance of previous day. the price risk of shallots is 3.055 percent of the total revenue received by farmers with a one-day sales period. This means an increase in revenue of one rupiah will increase the risk of shallot is by 3.05 percent.

Efforts to overcome price volatility of shallot can be done through an integrated effort between farmers, government traders and other parties. Cooperation undertaken between the various parties should be accompanied by consistency and strong commitment such as continuous coaching and good supervision. This is done so that in an effort to achieve the expected results can be more efficient.

\section{REFERENCES}

Firdaus M. 2006. Analisis Deret Waktu Satu Ragam. IPB Press : Bogor

Gaynor PE, Kirckpatrick RC. 1994. Introduction to Timeseries Modelling and Forecasting in Business and Economics. Mc Graw-Hill, Inc : Singapura.

Hyman DN. 1996. Microeconomics. New York : McGrawHill,Inc

Jorion P.2002. Value at Risk : the new benchmark for managing financial risk, second edition. McGraw-

Hill. California. North America.

Kementerian Pertanian. 2015. Keragaan Pembangunan Hortikultura http://hortikultura.pertanian.go.id/wpcontent/uploads/2015/06/Bab-III.pdf. Diakses tanggal 11 Juni 2017

Kountur, R. 2004. Manajemen Risiko Operasional (Memahami Cara Mengelola Risiko Operasional Perusahaan. PPM. Jakarta.

Lipsey RG, Courant PN, Purvis DD, Steiner PO. 1995. Pengantar Mikroekonomi. Jaka W dan Kirbrandoko, penerjemah; Jakarta: Binarupa Aksara. Terjemahan dari: Economis $10^{\text {th }}$ ed

McConnel CR, Brue SL. 1990. Microeconomics, Principles, Problems and Policies. New York : McGraw-Hill, IncPrajnanta F. 1999. Agribisnis Cabai Hibrida. Penebar Swadaya : Jakarta

Pyndyck RS, Rubinfeld, DL. 1983. Econometric Models And Economic Forecasts. Japan : McGraw-Hill, Inc

Robison, L.J. and P.J Barry. 1987. The Competitive Firm's Response To Risk. Macmillan Publishing Company. New York.

Sukirno S. 1985. Pengantar Teori Mikroekonomi. Jakarta : Lembaga Penerbit Fakultas Ekonomi UI

Wihono, Achmad. 2009. Analisis Volatilitas Harga Sayuran Di Pasar Induk Keramat Jati. Institut Pertanian Bogor 